\title{
Sex determination from dental pulp DNA among Egyptians
}

\author{
M. Kholief ${ }^{1}$, S. El Shanawany ${ }^{1}$ and R. Gomaa ${ }^{1,2^{*}}$ (i)
}

\begin{abstract}
Background: A great challenge arises when sex determination of human remains is needed, especially when only, bone fragments or isolated teeth are available; such as in mass disasters. Thus, the aim of the present work is to extract and analyze the DNA from dental pulp for sex determination of a sample of Egyptian population using the polymerase chain reaction amplification of DYS14 and SRY genes.

Materials and methods: DNA was extracted from the dental pulp of forty freshly extracted teeth (sound and carious) collected from adult Egyptians of both sexes using QIAamp DNA Investigator Kit. Androgen Receptor gene was PCR amplified as an internal positive control. DYS14 and SRY genes were PCR amplified for sex determination.

Results: DNA extraction was confirmed by detection of the amplified AR gene band ( $292 \mathrm{bp}$ ) in all samples. Sex was successfully determined for all the studied teeth as revealed by amplification of 158 bp band, 778 bp band of the DYS14 and SRY genes respectively.

Conclusion: DYS14 and SRY genes were found to be reliable for dental sex determination regardless of the condition of teeth, whether sound or carious.
\end{abstract}

Keywords: Sex determination, Dental pulp, DNA, PCR, DYS14 gene, SRY gene

\section{Background}

Forensic odontology is a critical subspecialty of forensic medicine as it contributes to proper and accurate identification of individuals in mass disasters and crime scene investigations. Therefore, it is considered as indispensable science for achieving justice (Nuzzolese \& Di Vella, 2007; Saxena et al., 2010).

Accurate determination of individual sex exemplifies a valuable clue in human identification, as it immediately excludes approximately one half of the population. The identification based on dental charts fails in some cases due to the lack of ante-mortem records, so DNA typing techniques are needed for exact personal identification (Williams et al., 2004).

Teeth are considered to be the ideal organ to estimate sex from fragmented, decomposed or burnt bodies as they are highly mineralized and most resistant to heat and decomposition. Hence, they represent an excellent

\footnotetext{
* Correspondence: drgomaa14@gmail.com

${ }^{1}$ Forensic Medicine and Clinical Toxicology Department, Faculty of Medicine, Alexandria University, Alexandria, Egypt

${ }^{2}$ College of Biotechnology, University of Modern Sciences, Dubai, United Arab Emirates
}

source to obtain genetic material (Gaytmenn \& Sweet, 2003a; Sweet, 2001).

Dental pulp is a preferable source for DNA extraction, as it is surrounded by hard mineralized tissues, which protects it against postmortem insults (Williams et al., 2004). It consists of connective tissue containing nerves, blood and lymphatic vessels. (Ash \& Nelson, 2014) This provides the greatest quantity of DNA, compared to other dental tissues (Pinchi et al., 2011).

With technological advances of molecular biology in forensic medicine, Polymerase Chain Reaction (PCR) offers efficient and sensitive methods for sex determination through the analysis of gender specific sequences on X and Y chromosomes (Akane et al., 1991).

$\mathrm{X}$ chromosome contains the Androgen Receptor (AR) gene, that is located on the long arm of $\mathrm{X}$ chromosome (Xq 11-12), so this gene can be identified in any male or female DNA sample (Omrani, 2006).

A sex determining region on the short arm of Y chromosome(SRY gene) is located at p11-31, thus, its detection is an indicator of male sex (Skaletsky et al., 2003; Thangaraj et al., 2002a; Jobling et al., 2007). However, 


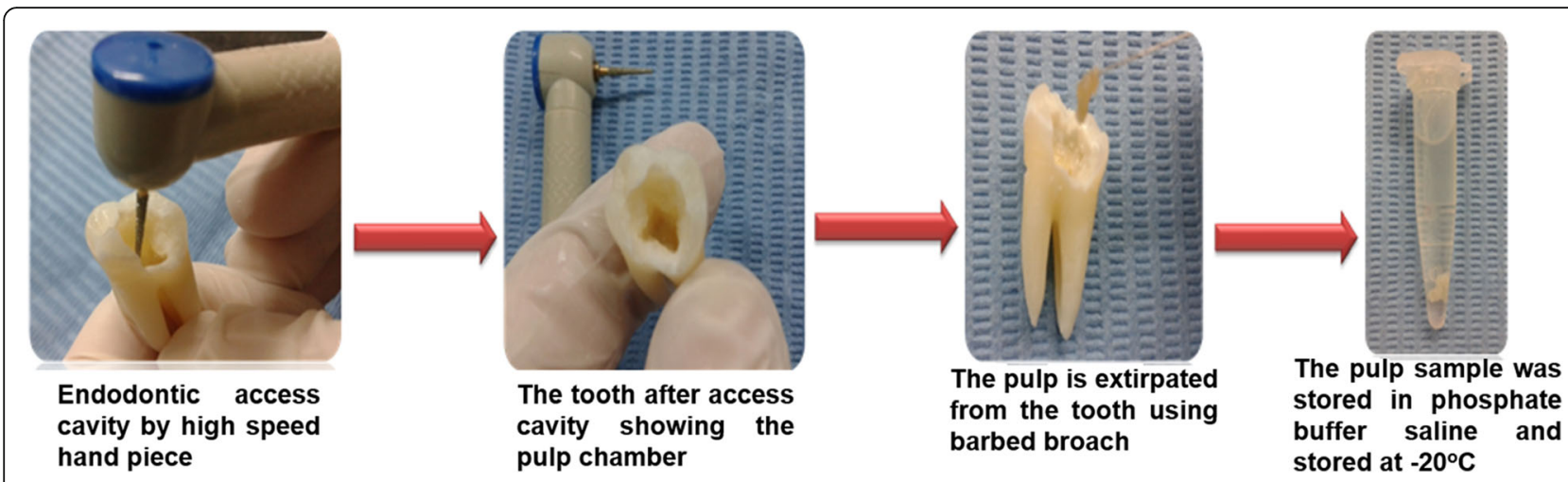

Fig. 1 Extraction of dental pulp tissue by standard endodontic access and pulp storage

much attention has been lately given to the DYS14 gene as a marker located in intron 1 of the multicopy Yencoded Testis-Specific Protein (TSPY) that plays a role in spermatogenesis. A single $\mathrm{Y}$ chromosome contains, on average, more than 50 copies of this gene, each copy carries the DYS14 marker. Thus, it is recommanded to be easily looked for in poor quality DNA or low copy number (Zimmermann et al., 2008).

DYS14 gene was used as a non- invasive method for fetal sex determination from maternal plasma (FernándezMartínez et al., 2012). Nowadays, it is used for identification of male DNA in mixed male and female samples in case of sexual assaults (Kamodyová et al., 2013).

The purpose of the current study was to extract and analyze DNA from the dental pulp of a sample of Egyptian adult individuals for sex determination using polymerase chain reaction amplification of SRY and DYS14 genes.

\section{Materials and methods}

\section{Materials}

The present study was conducted on 40 freshly extracted teeth from adult Egyptian patients of both sexes with an age range from 19 to 58 years, attending different dental hospitals and clinics.

All teeth were evaluated using radiographs to verify the presence or absence of pulp space.

\section{Inclusion criteria}

Freshly extracted teeth from all quadrants for orthodontic, periodontal or prosthetic reasons were included regardless to the presence or absence of caries.

\section{Exclusion criteria}

Previously restored teeth with any filling material, in addition to grossly damaged teeth as well as completely calcified teeth were all excluded from the study.

\section{Methods}

Informed consent was obtained from all participants, as well as approval of the Medical Ethics Committee of Faculty of Medicine, Alexandria University.

\section{Sample Preparation}

All the extracted teeth were decontaminated to eliminate external contaminants present on the exterior surface that could potentially affect the quality of the collected DNA. Handling of the teeth was under aseptic conditions using sterile instruments and disposable gloves. The decontamination process was performed by immersing the teeth in $0.9 \%$ isotonic saline solution for $15 \mathrm{~min}$, then washing with distilled water.

\section{Pulp Extirpation and Storage: (Fig. 1)}

The pulp chamber of each tooth was accessed through the occlusal surface of the teeth by a high speed air driven hand piece. Following that, the pulp was carefully removed using a barbed broach avoiding the shredding effect. Finally, the pulp was placed in a sterile $1.5 \mathrm{ml}$ labeled Eppendorf tube containing phosphate buffer saline and stored at $-20{ }^{\circ} \mathrm{C}$ till DNA extraction was performed.

Table 1 AR, SRY and DYS14-specific primers sets and base sequences. (Mohammed \& Tayel, 2005; Gomaa \& Sheta, 2013)

\begin{tabular}{ll}
\hline Primer & Sequence 5'-3' \\
\hline AR Forward & CTCTGGGCTTATTGTAAACTTCC \\
AR Reverse & GTCCAGGAGCTGGCTTTCCCTA \\
SRY forward & GGTGTGAGGGCGGAGAAATGC \\
SRY Reverse & GTAGCCAATGTTACCCGATTGTC \\
DYS14 Forward & CATCCAGAGCGTCCCTGG \\
DYS14 Reverse & TTCCCCTTTGTCCCCAAA \\
\hline
\end{tabular}


Table 2 PCR program for amplification of AR, SRY and DYS14 genes

\begin{tabular}{|c|c|c|c|}
\hline Steps & PCR Program for AR gene & PCR Program for SRY gene & PCR Program for DYS14 gene \\
\hline Initial denaturation & $95^{\circ} \mathrm{C}$ for 10 mins & $95^{\circ} \mathrm{C}$ for 10 mins & $95^{\circ} \mathrm{C}$ for 10 mins \\
\hline Denaturation & $95^{\circ} \mathrm{C}$ for $20 \mathrm{~s}$ & $95^{\circ} \mathrm{C}$ for $1 \mathrm{~min}$. & $95^{\circ} \mathrm{C}$ for $30 \mathrm{~s}$ \\
\hline Annealing & $72^{\circ} \mathrm{C}$ for 1 min. $^{\text {a }}$ & $58{ }^{\circ} \mathrm{C}$ for 1 min. & $60{ }^{\circ} \mathrm{C}$ for $30 \mathrm{~s}$ \\
\hline Extension & & $72^{\circ} \mathrm{C}$ for $1 \mathrm{~min}$. & $72{ }^{\circ} \mathrm{C}$ for $30 \mathrm{~s}$ \\
\hline Number of cycles & 35 cycles & 35 cycles & 35 cycles \\
\hline Final extension & $72^{\circ} \mathrm{C}$ for 7 mins & $72^{\circ} \mathrm{C}$ for 10 mins & $72^{\circ} \mathrm{C}$ for 10 mins \\
\hline
\end{tabular}

${ }^{a}$ Annealing and extension steps are combined together in one step

3. Detection of Androgen Receptor and Sex Determining Genes

All subsequent experiments were performed blindly and sex results were cross matched at the end of the study.

\section{DNA Extraction "Solid Phase Extraction":}

After complete thawing of the frozen sample, the storage buffer (phosphate buffer saline) was withdrawn and discarded, leaving the dental pulp in the Eppenderof tube.

The extraction procedures were performed according to the QIAamp DNA investigator kit protocol (QIAamp ${ }^{\circ}$ DNA Investigator Handbook, 2010).

\section{DNA amplification:}

SRY and DYS14 genes were amplified for sex determination by using a conventional singleplex Polymerase Chain Reaction (PCR) technique. Negative control was rum throughout all the experiments using molecular biological water to detect any possible contamination. AR gene was amplified as an internal positive control.
For each reaction, the following constituents were added to a $200 \mu \mathrm{l}$ PCR tube containing a PCR bead: (Illustra pure Taq Ready-To-Go PCR Beads, n.d.).

- $0.5 \mu \mathrm{l}$ (forward) primer, $0.5 \mu \mathrm{l}$ (reverse) primer (Table 1).

- $5 \mu$ l extracted DNA.

- $19 \mu$ sterile molecular biology water to reach a final volume of $25 \mu \mathrm{l}$.

Thermal cycling was performed for the three genes using different conditions (Table 2).

\section{Visualization of PCR products: (Denomme et al., 2007)}

PCR products were checked via gel electrophoresis on a $2 \%$ agarose gel containing ethidium bromide and visualized using UV gel documentation system. The images were captured and saved.

\section{Results}

Absence of bands in negative control samples indicated proper decontamination techniques.

All dental pulp samples showed the amplified bands of androgen receptor gene (292 bp) indicating successful DNA extraction as shown in (Fig. 2).

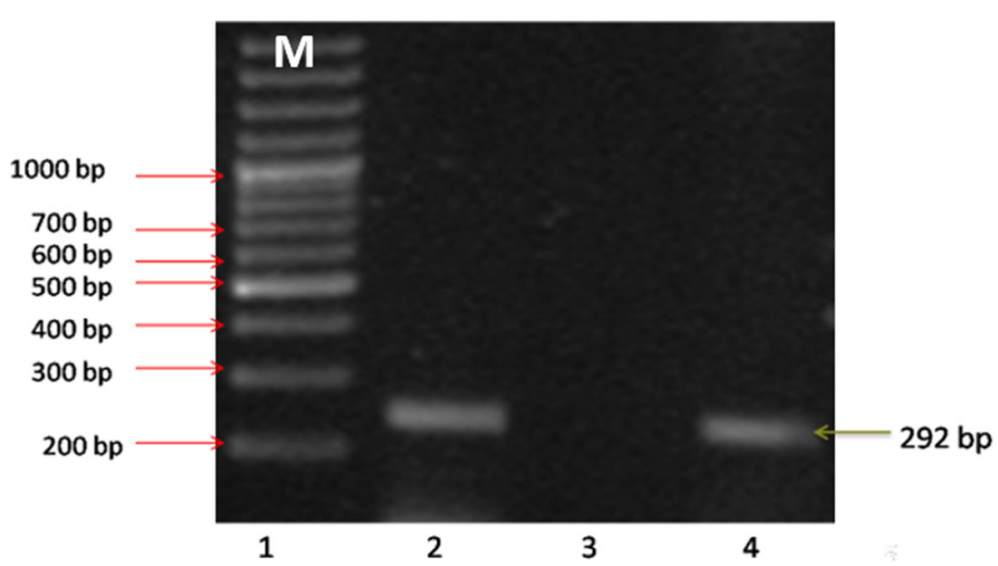

Fig. 2 Singleplex PCR amplification of AR gene on X chromosome (292 bp). Lanes: $1(M)=100$ bp DNA hyperladder, Lanes 2, $4=$ bands of AR of either male or female dental pulp samples, lane 3 = negative control (molecular biology water) 


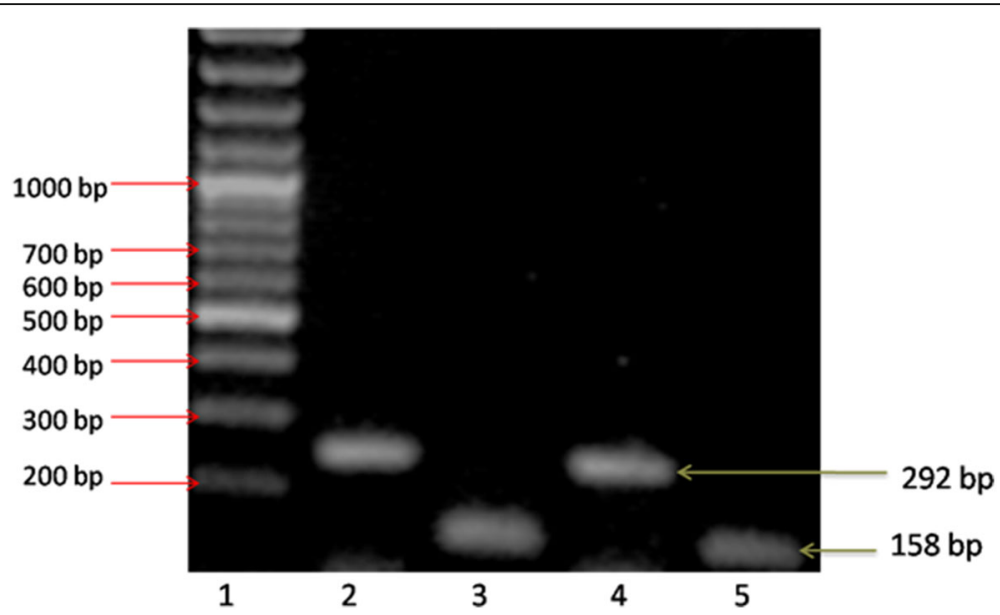

Fig. 3 Singleplex PCR amplification of DYS14 gene (158 bp) and AR gene (292 bp). Lanes: $1(M)=100$ bp DNA ladder, lanes 2, $3=$ bands of AR gene at 292 bp and DYS14 gene at 158 bp respectively in the same dental pulp sample, lanes 4, $5=$ bands of AR gene and DYS14 gene respectively in another sample. Both samples were of the male sex

Twenty four dental pulp samples showed the amplified bands of DYS14 gene (158 bp) and bands of SRY gene (778 bp) indicating male sex. However, the rest of the samples (16 teeth) showed no bands of either DYS14 or SRY gene in spite of displaying the amplified bands of the positive control AR gene ( $292 \mathrm{bp}$ ) that leads to identification of the female sex (Figs. 3, 4, and 5).

As regards to the tooth status, DNA was successfully extracted as proved by AR gene amplification in all the studied pulp samples, whether from sound or carious teeth. Furthermore, the condition of the teeth did not affect the process of DYS14 or SRY gene where both showed their bands in all the studied male samples, whether extracted from sound or carious teeth (Figs. 6, 7).

At the end of the DNA analysis, results were compared to the original sex data of the dental pulp samples and showed $100 \%$ success of the process of sex determination using the studied genes with no false positive or false negative results.

\section{Discussion}

With the increasing rate of violence, crimes and terrorism with advancement of weapons used, proper human identification is required for legal and humanitarian reasons which is considered as a challenging field of study and research in forensic science. In this regard, many studies have used the dental pulp for sex determination (Veeraraghavan et al., 2010; Zapico \& Ubelaker, 2013; Nogami et al., 2008; Nayar et al., 2014; Naik et al., 2012).

A single tooth may be the sole evidence presented in the scene and being the most durable tissue enclosing a rich vascular network; that is why the tooth pulp was chosen for sex determination in the present study.

Decontamination procedure which was applied in the present study, did not include any bleaching agents or detergents, in contrast to that were applied in the previous studies (Sweet \& Hildebrand, 1998; Gaytmenn \& Sweet, 2003b; Kemp \& Smith, 2005; Marjanovic et al., 2007; Alakoc \& Aka, 2009).

(Higgins et al., 2013), proved that bleaching agents decreased the amount of DNA yield in comparison to non- bleach treated teeth. Therefore, in the present work we did not use this method of decontamination to avoid destruction of DNA or dissolution of the pulp.

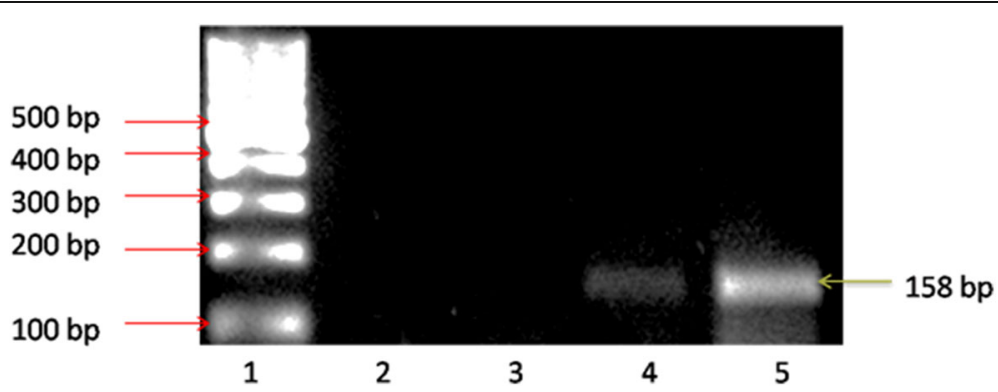

Fig. 4 Singleplex PCR amplification of DYS14 gene (158 bp). Lanes: 1(M) = 100 bp DNA ladder, lanes 2, 3= no bands at 158 bp denoting female samples, lanes 4, $5=$ male samples with bands at $158 \mathrm{bp}$ 


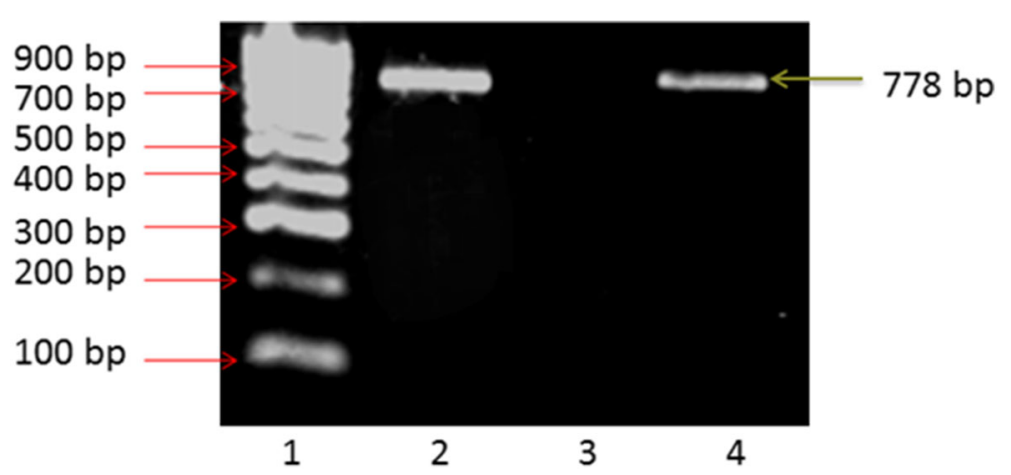

Fig. 5 Singleplex PCR amplification of SRY gene (778 bp). Lanes: 1 $(M)=100$ bp DNA ladder, lanes 2, 4 = male samples with bands at 778 bp, lane $3=$ no band at $778 \mathrm{bp}$ denoting female sample

Actually there were no cases of external DNA contamination encountered in this study, as the androgen receptor gene was successfully amplified in all the samples. This denotes the effectiveness of the used decontamination method.

To access the dental DNA, many authors crushed the whole tooth (Sweet \& Hildebrand, 1998; Sivagami et al., 2000; Meyer et al., 2000; Baker et al., 2001; Rubio et al., 2009), while others preferred sectioning the tooth (Gaytmenn \& Sweet, 2003b; Murakami et al., 2000; Shiroma et al., 2004; PreseEki et al., 2000). The main drawback of the crushing method is that it completely destroys the teeth which is hindering further investigations. In sectioning the teeth, the access to the pulp chamber, by clear fracture, needs an experienced dentist. It is also difficult to perform teeth sectioning in case of pulp retraction (Tilotta et al., 2010).

In agreement with (Tilotta et al., 2010), the pulp was successfully extirpated in the current study by a standard endodontic access. The main advantage of this method is being conservative, so the tooth can be used for further investigation. It is also performed under air and water spray to prevent heating, whereas crushing or sectioning produces heat which may damage the genetic material (Tilotta et al., 2010). However, the endodontic access method utilized in this study required the need for a skilled dentist where the pulp was extracted with sufficient quality and quantity even from elder teeth.

The DNA extraction protocol used in the current study was based on solid phase extraction using silica- based column in contrary to other studies, where researchers used the classical organic extraction (phenol-chloroform method) (Sweet \& Hildebrand, 1998; Murakami et al., 2000; Michaelis et al., 2008; Bulter, 2012).

The phenol chloroform method had many disadvantages including time consumption, difficulty and demanding of large quantity of samples which is not always available in real forensic investigations. Moreover, it requires the sample to be transferred between multiple tubes and this increases the risk of contamination. Also, handling of hazardous chemicals in this method poses a risk on the researchers (Michaelis et al., 2008; Bulter, 2012).

Utilizing the silica- based spin columns resulted in successful extraction of DNA from dental pulp samples

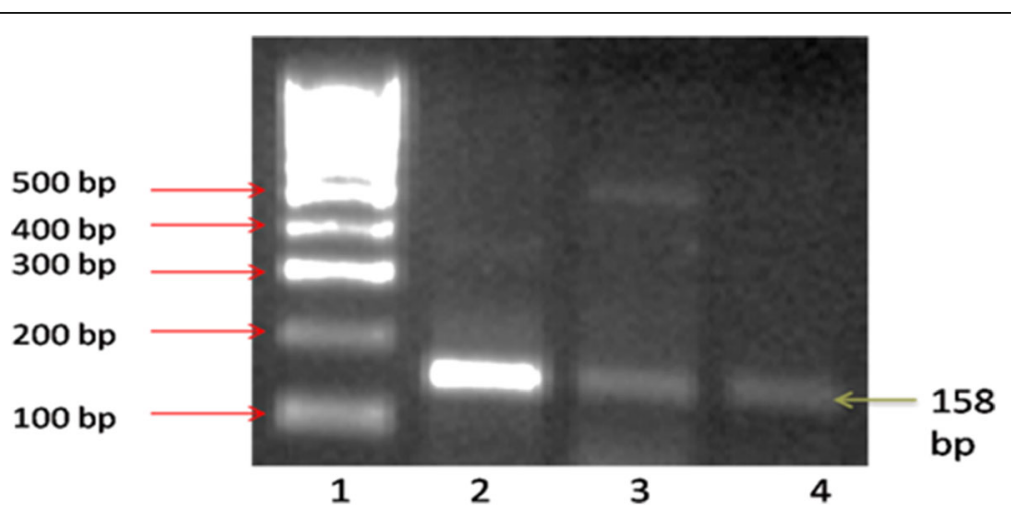

Fig. 6 Singleplex PCR amplification of DYS14 gene (158 bp). Lanes: 1(M) = 100 bp ladder, lanes 2, 4 = male samples from two sound teeth, lane 3 = male sample from a carious tooth 


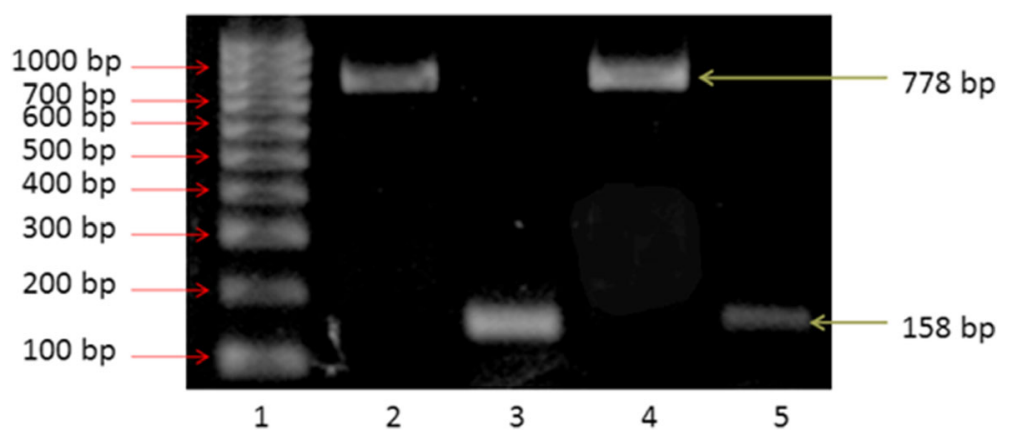

Fig. 7 Singleplex PCR amplification of DYS14 gene (158 bp), SRY gene (778 bp). Lanes: $1(M)=100$ bp DNA ladder, lanes 2, $3=$ male samples from one sound tooth, lanes 4, 5 =male samples from one carious tooth

with the ability to determine the desired elution volume that allowed maximum concentration of DNA, which was chosen to be $40 \mu \mathrm{l}$ in the present study.

Sex determination was successfully achieved in all the studied samples with the use of SRY and DYS14 genes. Moreover, the age of participants had no impact on the potentials for sex determination.

Choosing SRY gene was based on its successful detection in different samples e.g.: blood, saliva, teeth and even from epithelial cells adhered to the bristles of tooth brushes (Vikram Simha Reddy et al., 2011).

Following several studies that showed deletions in the amelogenin gene on Y chromosome and subsequently the wrong identification of males as females, there was a definite need to use other reliable sex determining genetic markers (Kastelic et al., 2009; Kashyap et al., 2006; Chang \& Burgoyne, 2003; Thangaraj et al., 2002; Drobnic, 2006; Laverde, 2013).

The multi-copy DYS14 gene was not conventionally used for sex determination in forensic cases, therefore, it was used in this study to verify its efficacy for sex determination from the tooth pulp. (Nakata et al., 2010) and (Blagodatskikh et al., 2010) previously reported its success in identifying sex from prenatal and blood samples. Additionally, (Gomaa \& Sheta, 2013) have used DYS14 gene to identify male DNA in a mixture of male and female blood samples in varying proportions.

To compare between the sensitivity of DYS14 gene and SRY gene for sex determination using dental pulp samples, real time PCR would be adventitious in measuring the quantity of the amplified DNA bands. Thus, real time PCR is recommended for future studies to verify the contradictory findings reported by (Blagodatskikh et al., 2010) who documented that SRY gene showed ten times higher sensitivity than DYS14 gene. Whereas, other contradictory studies recommended DYS14 marker for the diagnosis of fetal gender from maternal plasma, and this recommendation was based on their findings which showed higher sensitivity of DYS14 over the SRY gene (Fernández-Martínez et al., 2012; Jacob et al., 2015; Khorshid et al., 2013). Hence, using conventional PCR in the present study provided $100 \%$ success in sex determination from all dental pulp samples with no false negative or positive results.

\section{Conclusion}

The dental pulp can be considered as a highly reliable source of DNA irrespective to the tooth status whether sound or carious. Particularly, the molar tooth which is considered as a good source of DNA since it is a multirooted tooth with the largest pulp volume. In addition, access to the pulp using the standard occlusal endodontic technique provides a significantly large amount of pulp tissue and subsequently sufficient amount of DNA yield with a minimal risk of contamination. Furthermore, DYS14 gene was proved to be as efficient as SRY gene for sex determination from the dental pulp using conventional PCR amplification with no false negative or positive results.

\section{Acknowledgements}

After success of the study, we would like to acknowledge the dentist who helped us in teeth extraction from all participants and taught us pulp extraction from teeth. Additionally, a great appreciation must go to all participants who gave approval to give their teeth to be included in the study. Finally, we would like to acknowledge University of Alexandria who funded that project.

\section{Funding}

This research was funded by the Faculty of Medicine at Alexandria University, Egypt.

\section{Availability of data and materials}

The datasets generated during and/or analyzed during the current study are available from the corresponding author on reasonable request.

\section{Authors' contributions}

MK (collection of samples and participation in the practical work, in addition to collection of literature review); SS (writing the discussion section and editing the whole article); RG (the idea of the study, conduction and supervision of the laboratory work and writing methodology and results). All authors read and approved the final manuscript.

\section{Ethics approval and consent to participate}

Ethical approval was obtained from the Medical Ethics Committee of Faculty of Medicine, Alexandria University, Egypt. In addition, a detailed written informed consent was obtained from all participants after explaining all details of the nature of the study and emphasizing that all information that will be collected from patients or obtained from the study will be kept confidential and will only be used solely for research purposes. 


\section{Consent for publication}

Not applicable.

\section{Competing interests}

The authors declare that they have no competing interests.

\section{Publisher's Note}

Springer Nature remains neutral with regard to jurisdictional claims in published maps and institutional affiliations.

Received: 31 May 2017 Accepted: 4 December 2017 Published online: 16 December 2017

\section{References:}

Akane A, Shiono H, Matsubara K, Nakahori Y, Seki S (1991) Sex identification of forensic specimens by polymerase chain reaction $(P C R)$ : two alternative methods. Forensic Sci Int 49(1):81-88

Alakoc YD, Aka PS (2009) "Orthograde entrance technique" to recover DNA from ancient teeth preserving the physical structure. Forensic Sci Int 188(1-3):96-98

Ash MM, Nelson SJ (2014) Wheeler's dental anatomy, physiology and occlusion, 8th edn. Saunders Elsevier, St. Louis, pp 6-8

Baker LE, McCormick WF, Matteson KJA (2001) Silica-based mitochondrial DNA extraction method applied to forensic hair shafts and teeth. J Forensic Sci 46(1):126-130

Blagodatskikh EG, Nikitin AG, Seregin YA, Blagodatskikh KA, Nosikov W (2010) Sex determination in biological specimens using the DYS14 marker. Mol Biol 44(4):568-570

Bulter JM (2012) Advanced topics in forensic DNA typing: methodology. Elsevier, USA, pp 1-47

Chang YM, Burgoyne LA (2003) Both K. Higher failures of amelogenin sex test in an Indian population group. J Forensic Sci 48:1309-1313

Denomme GA, Rios M, Reid ME (2007) Molecular protocols in transfusion medicine. Elsevier, USA, pp 1-41

Drobnic KA (2006) New primer set in a SRY gene for sex identification. Int Congr Ser 1288:268-270

Fernández-Martínez FJ, Galindo A, Garcia-Burguillo A, Gallego CV, Nogués N, Moreno-García M et al (2012 Jan) Noninvasive fetal sex determination in maternal plasma: a prospective feasibility study. Genet Med 14(1):101-106

Gaytmenn R, Sweet D (2003a) Quantitation of forensic DNA from various regions of human teeth. J Forensic Sci 48:622-625

Gaytmenn R, Sweet D (2003b) Quantification of forensic DNA from various regions of human teeth. J Forensic Sci 48(3):622-625

Gomaa R, Sheta A (2013) Identification of male DNA in male and female mixtures of forensic samples: implications in crime scene investigations. Proceedings of the 1st annual international conference on forensic sciences and criminalistics research (FSCR). Global science and technology forum digital. Library

Higgins D, Kaidonis J, Townsend G, Hughes T, Austin JJ (2013) Targeted sampling of cementum for recovery of nuclear DNA from human teeth and the impact of common decontamination measures. Investig Genet 4:18

Illustra pure Taq Ready-To-Go PCR Beads. Product booklet. Code: 27-9559-01. http://www.gelifesciences.com

Jacob RR, Saxena R, Verma IC (2015) Noninvasive Diagnosis of Fetal Gender: Utility of combining DYS14 and SRY. Genet test Mol biomarkers 19(9):505-511

Jobling MA, Lo CC, Turner DJ, Bowden GR, Lee AC, Wue Y et al (2007) Structural variation on the short arm of the human $Y$ chromosome: recurrent multigene deletions encompassing amelogenin Y. Hum Mol Genet 16(3):307-316

Kamodyová N, Durdiaková J, Celec P, Sedláčková T, Repiská G, Sviežená B et al (2013) Prevalence and persistence of male DNA identified in mixed saliva samples after intense kissing. Forensic Sci Int Genet 7(1):124-128

Kashyap VK, Sahoo S, Sitalaximi T, Trivedi R (2006) Deletions in the Y-derived amelogenin gene fragment in the Indian population. BMC Med Genet 7:37

Kastelic V, Budowle B, Drobnic K (2009) Validation of SRY marker for forensic casework analysis. J Forensic Sci 54:551-555

Kemp BM, Smith DG (2005) Use of bleach to eliminate contaminating DNA from the surface of bones and teeth. Forensic Sci Int 154(1):53-61

Khorshid RK, Zargari M, Sadeghi MR, Edallatkhah H, Shahhosseiny MH, Kamali K (2013) Early fetal gender determination using real-time PCR analysis of cell-free fetal DNA during 6th-10th weeks of gestation. Acta Medica Iranica 51(4):209-214

Laverde $L$ (2013) Sex determination problems in forensic genetic analysis. Forensic Science International: Genetics Supplement Series 4:e350-e351
Marjanovic D, Durmic-Pasic A, Bakal N, Haveric S, Kalamujic B, Kovacevic L et al (2007) DNA identification of skeletal remains from the world war II mass graves uncovered in Slovenia. Croat Med J 48(4):513-519

Meyer E, Wiese M, Bruchhaus H, Claussen M, Klein A (2000) Extraction and amplification of authentic DNA from ancient human remains. Forensic Sci Int 113(1-3):87-90

Michaelis RC, Flanders RG, Wulff PH (2008) A Litigator's guide to DNA: from the laboratory to the court room. USA: Elsevier:27-54

Mohammed F, Tayel SM (2005) Sex identification of normal persons and sex reverse cases from bloodstains using FISH and PCR. J Clin Forensic Med 12:122-127

Murakami H, Yamamoto Y, Yoshitome K, Ono T, Okamoto O, Shegita Y et al (2000) Forensic study of sex determination using PCR on teeth samples. Acta Med Okayama 54(1):21-32

Naik PR, Acath DD, Sharma GH, Navalkar AR (2012) Viability of human dental pulp in sex determination of sex of an individual by identifying SRY gene through DNA analysis: a single blind pilot study. J Indian aca oral. Med Radiol 24(2):133-136

Nakata N, Wang Y, Bhatt S (2010) Trends in prenatal screening and diagnostic testing among women referred for advanced maternal age. Prenatal Diagn 30:198-206

Nayar A, Singh HP, Leekha S (2014) Pulp tissue in sex determination: a fluorescent microscopic study. J Forensic Dent Sci 6:77-80

Nogami H, Tsutsumi H, Komuro T, Mukoyama R (2008) Rapid and simple sex determination method from dental pulp by loop-mediated isothermal amplification. Forensic Science International: Genetics 2:349-353

Nuzzolese E, Di Vella G (2007) Future project concerning mass disaster management: a forensic odontology prospectus. Int Dent J 57:261-266

Omrani MD (2006) Androgen receptor gene trinucleotide repeats as a marker for tracing disease in a family with intersex patients. J Repord Med 4(1):41-44

Pinchi V, Torricelli F, Nutini AL, Conti M, lozzi S, Norelli GA (2011) Techniques of dental DNA extraction: some operative experiences. Forensic Sci Int 204:111-114

PreseEki Z, BrkiE H, Primorac D, Drmic I (2000) Methods of preparing the tooth for DNA isolation. Acta Stomatol Croat 34:21-24

QIAamp ${ }^{\oplus}$ DNA Investigator Handbook. Catalog no. 56504. 4/ 2010. www.qiagen.com

Rubio L, Martinez LJ, Martinez E, Martin de las Heras S. Study of short- and long-term storage of teeth and its influence on DNA. J Forensic Sci 2009; 54(6):1411-1413

Saxena S, Sharma P, Gupta N (2010) Experimental studies of forensic odontology to aid in the identification process. J Forensic Dent Sci 2(2):69-76

Shiroma CY, Fielding CG, Lewis Jr JA, Gleisner MR, Dunn KNA (2004) Minimally destructive technique for sampling dentin powder for mitochondrial DNA testing. J Forensic Sci 49:791-795

Sivagami AV, Rao AR, Varshney UA (2000) Simple and cost-effective method for preparing DNA from the hard tooth tissue, and its use in polymerase chain reaction amplification of amelogenin gene segment for sex determination in an Indian population. Forensic Sci Int 110(2):107-115

Skaletsky H, Kuroda-Kawaguchi T, Minx PJ, Cordum HS, Hillier L, Brown LG et al (2003) The male-specific region of the human $Y$ chromosome is a mosaic of discrete sequence classes. Nature 423:825-837

Sweet D (2001) Why a dentist for identification? Dent Clin N Am 45:237-251

Sweet D, Hildebrand D (1998) Recovery of DNA from human teeth by cryogenic grinding. J Forensic Sci 43(6):1199-1202

Thangaraj K, Reddy AG, Singh LI (2002) The amelogenin gene reliable for gender identification in forensic casework and prenatal diagnosis? Int J Legal Med 116:121-123

Thangaraj K, Reddy AG, Singh LI (2002a) The amelogenin reliable for gender identification in forensic casework and prenatal diagnosis? Int J Legal Med 116:121-123

Tilotta F, Brousseau P, Lepareur E, Yasukawa K, de Mazancourt P (2010) A comparative study of two methods of dental pulp extraction for genetic fingerprinting. Forensic Sci Int 202(1-3):e39-e43

Veeraraghavan G, Lingappa A, Shankara S, Mamatha GP, Sebastian BT, Mujib A (2010) Determination of sex from tooth pulp tissue. Libyan J Med 5:5084

Vikram Simha Reddy A, Sriram G, Saraswathi TR, Sivapathasundharam B (2011) Isolation of epithelial cells from tooth brush and gender identification by amplification of SRY gene. J Forensic Dent Sci 3:27-32

Williams D, Lewis M, Franzen T, Lissett V, Adams C, Whittaker D et al (2004) Sex determination by PCR analysis of DNA extracted from incinerated, deciduous teeth. Sci Justice 44(2):89-94

Zapico SC, Ubelaker DH (2013) Sex determination from dentin and pulp in a medicolegal context. JADA 144(12):1379-1385

Zimmermann BG, Maddocks DG, Avent ND (2008) Quantification of circulatory fetal DNA in the plasma of pregnant women. In: Prenatal Diagnosis. Humana Press, Totowa, NJ, pp 219-231 